Review began 01/07/2022 Review ended 01/15/2022 Published 01/18/2022

(c) Copyright 2022

Al Saad et al. This is an open access article distributed under the terms of the Creative Commons Attribution License CC-BY 4.0., which permits unrestricted use, distribution, and reproduction in any medium, provided the original author and source are credited.

\section{The Correlation Between Surgical Procedures and Quality of Life Among Sickle Cell Disease Patients: A Perspective Saudi Study}

Ali J. Al Saad ${ }^{1}$, Rayan A. Buhalim ${ }^{2}$, Faisal A. Al Jabr ${ }^{2}$, Abdulaziz M. Al Dehailan ${ }^{2}$, Abdulaziz A. Albahrani 2

1. Clinical Neuroscience, King Faisal University, Al-Ahsa, SAU 2. College of Medicine, King Faisal University, Al-Ahsa, SAU

Corresponding author: Rayan A. Buhalim, rayan.buhalim@gmail.com

\title{
Abstract
}

Introduction: Sickle cell disease (SCD) is among the common prevalent diseases in Saudi Arabia. It is associated with several complications that sometimes necessitate surgical procedures. Those patients can also have a lower quality of life (QoL) due to several reasons. Our aim in this study is to highlight the association between sociodemographic data, clinical data, and SCD-related surgeries in patients with their QoL.

Methods: A cross-sectional study was performed using a validated Arabic version of the World Health Organization QoL-BREF (WHOQOL-BREF) questionnaire distributed in electronic form. Male and female Arabic speakers (18+ years old) of Saudi origin were included in this study; those who did not meet these criteria were excluded.

Results: We distributed 309 questionnaires to the targeted subjects; however, only 204 met our inclusion criteria. Our findings revealed 135 female respondents and 69 male respondents. Interestingly, splenectomy was not significantly associated with a difference in all aspects of QoL in SCD patients. However, the data showed significantly lower respective mean scores for physical health $(\mathrm{p}=0.002 \& \mathrm{p}=0.022)$ and overall QoL ( $\mathrm{p}=0.024 \& \mathrm{p}=0.042$ ) for those who underwent cholecystectomy and hip arthroplasty. In contrast, shoulder arthroplasty appeared to be associated with significantly lower mean scores for physical health $(\mathrm{T}=-2.597$; $\mathrm{p}=0.010)$ and the environmental aspect of QoL $(\mathrm{T}=-2.016 ; \mathrm{p}=0.045)$.

Conclusion: Cholecystectomy, hip arthroplasty, and shoulder arthroplasty were significantly associated with lower QoL in SCD patients.

Categories: Psychiatry, General Surgery, Hematology

Keywords: heath related quality of life, total joint arthroplasty, post-splenectomy, post cholecystectomy, surgeries, kingdom of saudi arabia (ksa), surgical operation, sickle cell anemia, psychological impacts, mental health and psychiatry

\section{Introduction}

Sickle cell disease (SCD) is a major health problem in several countries [1]. This autosomal recessive disease results from a mutation in the $\beta$-globin chain due to the replacement of valine with glutamic acid at the sixth codon [2]. Worldwide, 300 million people carry the sickle cell trait (SCT), and 300,000 infants are born with SCD annually [3]. In the United States (US), SCD affects 72,000 people, and roughly 2 million are carriers [4]. In Saudi Arabia, the prevalence of SCD has not been widely studied. A community-based survey study found that the prevalence of SCD ranges from 6-145 per 10,000 people, with the highest prevalence in the Eastern Province [4-6]. This hereditary disease is pervasive in Saudi Arabia due to the high number of consanguineous marriages, which account for $56 \%$ of all marriages. Marriages between first cousins are the most common variation $[4,5,7]$.

A vaso-occlusive crisis is the most common presentation of SCD in patients, and it is responsible for major organ damage [5]. One of the earliest and most commonly affected organs is the spleen [8]. Splenic damage increases susceptibility to encapsulated organisms (for example, Streptococcus pneumoniae, Haemophilus influenzae, and Neisseria meningitidis) and necessitates splenectomy and subsequent antibiotic prophylaxis $[9,10]$. Fortunately, splenectomy has been shown to improve the general and mental health of SCD patients [11]. Another commonly affected organ is the gallbladder, and SCD patients frequently experience cholelithiasis due to their excess bilirubin production [9]. Moreover, 20-50\% of SCD patients suffer from femoral head osteonecrosis, altering their quality of life (QoL) and leading to debilitating consequences. Despite the high rate of perioperative complications, SCD patients with irreversible damage and compromised lifestyles are recommended to undergo early hip replacement surgery [12]. 
Measuring QoL in SCD patients could be critical to determining the efficacy of their treatments [13]. We hypothesized that performing SCD-related surgical procedures can improve patients' mental well-being, social lives, and daily lives. Therefore, this study aimed to determine the correlations between QoL and SCD-related surgeries in Saudi patients.

\section{Materials And Methods \\ Sample size and study procedure}

Based on a study conducted during a Saudi premarital screening program, we could potentially access 1251 patients with SCD [14]. Consequently, we determined an ideal sample size of 294 patients, with a $5 \%$ margin of error and a 95\% confidence interval(CI) [15]. We conducted a cross-sectional study using a convenient random sampling technique. An Arabic version of the abbreviated World Health Organization Quality of Life (WHOQOL-BREF) questionnaire was distributed to all SCD patients [16]. The data were collected from June to December 2020. The data included each patient's age, gender, and other sociodemographic information as well as their clinical history of SCD.

\section{Domain scores}

We measured health-related QoL with the WHOQOL-BREF, which produced a QoL profile for each patient. We considered this profile to be valuable if the disease treatment option was palliative rather than curative. The questionnaire had 26 questions: two questions on general QoL and 24 questions from the original WHOQOL (WHOQOL-100) instrument. The WHOQOL-100 divides these 24 questions into four domains: physical health (seven items), psychological health (six items), social relationships (three items), and environment (eight items). The domain scores are distributed in a positive direction; the higher the domain scores, the better the QoL [17].

\section{Statistical analysis}

When appropriate, we presented the descriptive statistics using numbers, percentages, means, and standard deviations. Moreover, we conducted between-group comparisons, the chi-squared test, the independent $t$ test, and the one-way analysis of variance (ANOVA) test whenever it was appropriate to do so. We used pvalues $<0.05$ to determine statistical significance. We also performed a correlation procedure to assess the linear relationship between the overall QoL and its domains. We conducted all data analyses using the IBM SPSS Statistics for Windows, Version 21.0 (Released 20121, IBM Corp., Armonk, New York).

\section{Inclusion and exclusion criteria}

We only included Saudi Arabic speakers over 18 years of age with SCD in this study. Hence, we excluded all other individuals.

\section{Ethical considerations}

The study was approved by the College of Medicine at King Faisal University, Hofuf, Saudi Arabia, and we ensured the participants' confidentiality.

\section{Results}

We distributed 309 questionnaires to the targeted subjects; 204 met our inclusion criteria. Table 1 presents the socio-demographic characteristics of the patients. The most common age group was less than 30 years (52.9\%), with the majority being females (66.2\%). Most of the respondents were living in the Eastern Province region $(n=117,57.4 \%)$. It was revealed that the prevalence of patients who were currently on medications was $72.1 \%$, the proportion of the patients in support groups was $22.5 \%$, while the percentage of patients admitted in the hospital in the last 12 months was $50.5 \%$. However, the patients who take hydroxyurea, folic acid, narcotics, and analgesics were $39.7 \%$, 30.4\%, 3.4\%, 5.9\%, respectively. The prevalence of patients who underwent surgical procedures was $58.3 \%$. Surgical procedures included cholecystectomy (32.8\%), splenectomy (14.7\%), hip arthroplasty (5.9\%), and shoulder arthroplasty (1\%).

\begin{tabular}{|l|l|}
\hline Study data & Overall \\
\hline & $\mathrm{N}(\%)$ \\
\hline Age group & $(\mathrm{n}=204)$ \\
\hline$\quad 30$ years & \\
\hline - 30 years & $108(52.9 \%)$ \\
\hline Gender & $96(47.1 \%)$ \\
\hline
\end{tabular}




\section{Cureus}

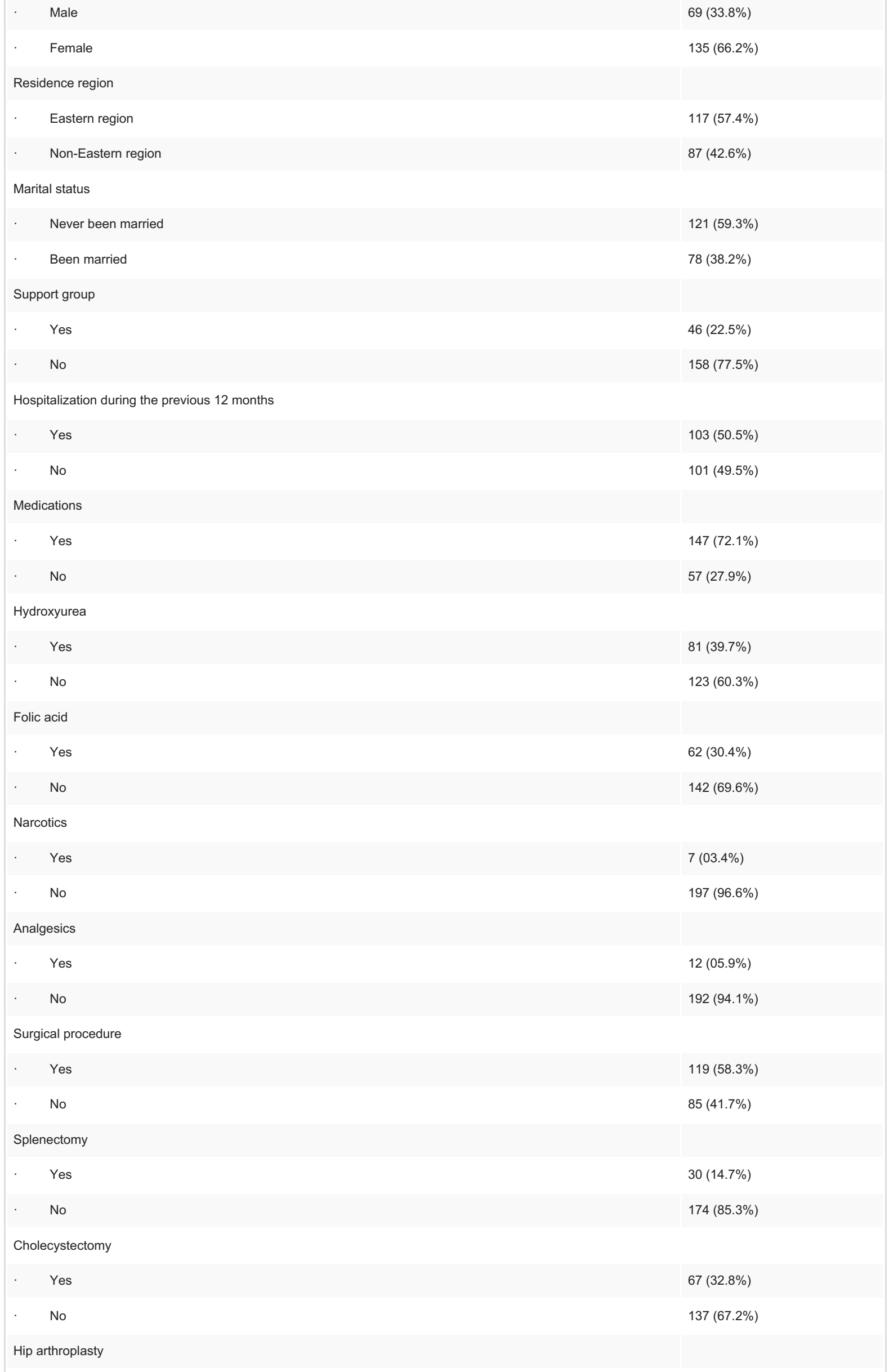




\section{Cureus}

Shoulder arthroplasty

Yes
$12(05.9 \%)$

$192(94.1 \%)$

$202(99.0 \%)$

\section{TABLE 1: Sociodemographic characteristics of patients}

Table 2 shows the association between the sociodemographic characteristics and QoL. It was found that patients who were younger (<30 years) showed statistically significantly higher mean scores in domain 1 $(\mathrm{T}=2.379 ; \mathrm{p}=0.018)$, domain $3(\mathrm{~T}=3.392 ; \mathrm{p}=0.001)$, domain $4(\mathrm{~T}=3.198 ; \mathrm{p}=0.002)$, and overall QoL $(\mathrm{T}=3.079$; $\mathrm{p}=0.002)$. We also observed that females showed significantly higher mean scores in domain 3 ( $\mathrm{T}=-2.318$; $\mathrm{p}=0.021)$. Furthermore, those living in the Eastern region exhibited significantly higher mean scores in domain $1(\mathrm{~T}=2.210 ; \mathrm{p}=0.028)$, domain 3 ( $\mathrm{T}=2.452 ; \mathrm{p}=0.015)$, and overall $\mathrm{QoL}(\mathrm{T}=2.029 ; \mathrm{p}=0.044)$. Similarly, those who were living alone had significantly better mean scores in domain 3 ( $F=3.513 ; \mathrm{p}=0.032$ ), domain 4 $(\mathrm{F}=4.105 ; \mathrm{p}=0.018)$, and overall $\mathrm{QoL}(\mathrm{F}=3.235 ; \mathrm{p}=0.041)$. In addition, those who had hospitalization during the last 12 months showed significantly lower mean scores in domain 1 ( $\mathrm{T}=-6.535 ; \mathrm{p}<0.001)$, domain 2 ( $\mathrm{T}=-$ 3.831; $\mathrm{p}<0.001)$, domain 3 ( $\mathrm{T}=-2.979 ; \mathrm{p}=0.003)$, domain $4(\mathrm{~T}=-4.964 ; \mathrm{p}<0.001)$, and overall $\mathrm{QoL}(\mathrm{T}=-5.273$; $\mathrm{p}<0.001)$. 


\section{Cureus}

\begin{tabular}{|c|c|c|c|c|c|}
\hline Factor & Domain 1 Mean \pm SD & Domain 2 Mean \pm SD & Domain 3 Mean \pm SD & Domain 4 Mean \pm SD & Overall Mean \pm SD \\
\hline \multicolumn{6}{|l|}{ Age group } \\
\hline$<30$ years & $67.0 \pm 15.6$ & $68.5 \pm 15.1$ & $70.1 \pm 17.1$ & $66.3 \pm 16.1$ & $67.9 \pm 13.5$ \\
\hline$\geq 30$ years & $61.8 \pm 16.0$ & $65.6 \pm 15.8$ & $61.0 \pm 20.8$ & $58.8 \pm 17.2$ & $61.8 \pm 15.1$ \\
\hline T-test & 2.379 & 1.357 & 3.392 & 3.198 & 3.079 \\
\hline P-value & $0.018^{* *}$ & 0.176 & $0.001^{\star *}$ & $0.002^{* *}$ & $0.002^{\star *}$ \\
\hline \multicolumn{6}{|l|}{ Gender } \\
\hline Male & $64.3 \pm 17.8$ & $65.7 \pm 16.4$ & $61.4 \pm 20.7$ & $60.1 \pm 18.1$ & $62.9 \pm 15.8$ \\
\hline Female & $64.7 \pm 15.1$ & $67.9 \pm 14.9$ & $68.0 \pm 18.4$ & $64.1 \pm 16.4$ & $66.2 \pm 13.8$ \\
\hline T-test & -0.156 & -0.963 & -2.318 & -1.579 & -1.525 \\
\hline P-value & 0.876 & 0.337 & $0.021^{* *}$ & 0.116 & 0.129 \\
\hline \multicolumn{6}{|l|}{ Residence region } \\
\hline Eastern & $66.7 \pm 16.9$ & $68.5 \pm 16.5$ & $68.7 \pm 19.2$ & $63.5 \pm 17.1$ & $66.8 \pm 15.3$ \\
\hline Non-Eastern & $61.7 \pm 12.3$ & $65.2 \pm 13.7$ & $61.9 \pm 19.2$ & $61.8 \pm 16.9$ & $62.7 \pm 13.2$ \\
\hline T-test & 2.210 & 1.519 & 2.452 & 0.708 & 2.029 \\
\hline P-value & $0.028^{* *}$ & 0.130 & $0.015^{* *}$ & 0.480 & $0.044^{* *}$ \\
\hline \multicolumn{6}{|l|}{ Marital status } \\
\hline Never been married & $66.3 \pm 14.7$ & $67.4 \pm 14.9$ & $66.6 \pm 17.4$ & $64.2 \pm 16.5$ & $66.1 \pm 13.2$ \\
\hline Been married & $62.0 \pm 17.5$ & $66.7 \pm 16.3$ & $64.7 \pm 22.1$ & $60.6 \pm 17.7$ & $63.5 \pm 16.3$ \\
\hline T-test & 1.875 & 0.337 & 0.704 & 1.484 & 1.268 \\
\hline P-value & 0.062 & 0.736 & 0.482 & 0.139 & 0.206 \\
\hline \multicolumn{6}{|l|}{ Hospitalization } \\
\hline Yes & $57.9 \pm 13.3$ & $03.1 \pm 75.1$ & $61.9 \pm 18.6$ & $57.2 \pm 16.5$ & $60.0 \pm 73.4$ \\
\hline No & $71.3 \pm 15.8$ & $71.2 \pm 14.8$ & $69.8 \pm 19.6$ & $68.4 \pm 15.8$ & $70.2 \pm 14.0$ \\
\hline I-test & -6.535 & -3.831 & -2.919 & -4.964 & -5.273 \\
\hline P-value & $<0.001^{\star \star}$ & $<0.001^{\text {** }}$ & $0.003^{\text {** }}$ & $<0.001^{\star \star}$ & $<0.001^{\star \star}$ \\
\hline \multicolumn{6}{|l|}{ Support group } \\
\hline Yes & $63.5 \pm 17.5$ & $66.9 \pm 14.8$ & $68.1 \pm 18.9$ & $65.0 \pm 16.9$ & $65.9 \pm 14.3$ \\
\hline No & $64.9 \pm 15.6$ & $67.2 \pm 15.6$ & $65.1 \pm 19.6$ & $62.1 \pm 17.1$ & $64.8 \pm 14.7$ \\
\hline I-test & -0.516 & -0.111 & 0.911 & 1.026 & 0.431 \\
\hline P-value & 0.606 & 0.911 & 0.363 & 0.306 & 0.667 \\
\hline
\end{tabular}

TABLE 2: Statistical difference between sociodemographic characteristics versus overall QoL and its domain $(n=204)$

Domain 1: Physical health; Domain 2: Psychological health; Domain 3: Social Relationship; Domain 4: Environmental; QoL: Quality of life.

P-value has been calculated using Independent t-test ** Significant at $p<0.05$ level.

Table 3 highlights the differences in the mean scores of OoL and its domain in relation to the medications and surgical procedures done for the patients. It was found that those who were taking medications showed significantly lower mean scores in domain $1(\mathrm{~T}=-4.334 ; \mathrm{p}<0.001)$ and overall $\mathrm{QoL}(\mathrm{T}=-2.685 ; \mathrm{p}=0.002)$. We 
also observed that patients taking hydroxyurea exhibited a lower mean score in domain 1 ( $T=-2.915$; $\mathrm{p}=0.004$ ), while those who were taking Folic acid also exhibited a lower mean score in domain 1 ( $\mathrm{T}=-2.841$; $\mathrm{p}=0.005$ ). Furthermore, those who were taking narcotics exhibited significantly less mean scores in domain 1 $(\mathrm{T}=-3.995 ; \mathrm{p}<0.001)$, domain $2(\mathrm{~T}=-2.431 ; \mathrm{p}=0.016)$, domain $3(\mathrm{~T}=-2.007 ; \mathrm{p}=0.046)$, domain $4(\mathrm{~T}=-2.792$; $\mathrm{p}=0.006)$, and overall $\mathrm{QoL}(\mathrm{T}=-3.229 ; \mathrm{p}=0.001)$ while those who were taking analgesics showed significantly lower mean score in domain $1(\mathrm{~T}=-3.041 ; \mathrm{p}=0.003)$. Moreover, those who underwent surgical procedures showed significantly lower mean scores in domain 1 ( $\mathrm{T}=-3.840 ; \mathrm{p}<0.001)$, domain $4(\mathrm{~T}=-2.211 ; \mathrm{p}=0.028)$, and overall QoL ( $\mathrm{T}=-2.427 ; \mathrm{p}=0.016)$. Similarly, those who underwent cholecystectomy exhibited significantly lower mean scores in domain $1(\mathrm{~T}=-3.062 ; \mathrm{p}=0.002)$ and overall QoL $(\mathrm{T}=-2.273 ; \mathrm{p}=0.024)$. Also, those with hip arthroplasty showed significantly less score in domain $1(\mathrm{~T}=-2.315 ; \mathrm{p}=0.022)$ and overall QoL $(\mathrm{T}=-2.043$; $\mathrm{p}=0.042)$ while those with shoulder arthroplasty observed to have significantly less score in domain $1(\mathrm{~T}=-$ $2.597 ; \mathrm{p}=0.010)$ and in domain $4(\mathrm{~T}=-2.016 ; \mathrm{p}=0.045)$.

\begin{tabular}{|c|c|c|c|c|c|}
\hline Factor & Domain 1 Mean \pm SD & Domain 2 Mean \pm SD & Domain 3 Mean \pm SD & Domain 4 Mean \pm SD & Overall Mean \pm SD \\
\hline \multicolumn{6}{|c|}{ Medications } \\
\hline Yes & $61.7 \pm 15.5$ & $65.8 \pm 15.6$ & $64.5 \pm 19.0$ & $61.5 \pm 17.1$ & $63.4 \pm 14.6$ \\
\hline No & $72.0 \pm 14.9$ & $70.4 \pm 14.7$ & $69.1 \pm 20.3$ & $66.0 \pm 16.5$ & $69.4 \pm 13.9$ \\
\hline T-test & -4.334 & -1.915 & -1.517 & -1.719 & -2.685 \\
\hline P-value & $<0.001^{* \star}$ & 0.057 & 0.131 & 0.087 & $0.008^{* \star}$ \\
\hline \multicolumn{6}{|c|}{ Hydroxyurea } \\
\hline Yes & $60.6 \pm 13.2$ & $65.6 \pm 14.9$ & $65.1 \pm 18.6$ & $60.2 \pm 16.2$ & $62.9 \pm 13.2$ \\
\hline No & $67.2 \pm 17.2$ & $68.1 \pm 15.7$ & $66.3 \pm 20.0$ & $64.4 \pm 17.4$ & $66.5 \pm 15.3$ \\
\hline T-test & -2.915 & -1.135 & -0.425 & -1.742 & -1.741 \\
\hline P-value & $0.004^{\star \star}$ & 0.258 & 0.671 & 0.083 & 0.083 \\
\hline \multicolumn{6}{|c|}{ Folic acid } \\
\hline Yes & $59.8 \pm 15.9$ & $64.7 \pm 16.9$ & $64.3 \pm 20.8$ & $61.8 \pm 17.2$ & $62.7 \pm 15.7$ \\
\hline No & $66.6 \pm 15.7$ & $68.1 \pm 14.7$ & $66.5 \pm 18.8$ & $63.2 \pm 17.0$ & $66.1 \pm 14.0$ \\
\hline T-test & -2.841 & -1.457 & -0.735 & -0.530 & -1.555 \\
\hline$P$-value & $0.005^{* *}$ & 0.147 & 0.463 & 0.597 & 0.122 \\
\hline \multicolumn{6}{|l|}{ Narcotics } \\
\hline Yes & $41.6 \pm 9.01$ & $53.3 \pm 4.30$ & $51.4 \pm 23.6$ & $45.4 \pm 13.0$ & $47.9 \pm 9.83$ \\
\hline No & $65.4 \pm 15.6$ & $67.6 \pm 15.5$ & $66.3 \pm 19.2$ & $63.4 \pm 16.9$ & $65.7 \pm 14.4$ \\
\hline T-test & -3.995 & -2.431 & -2.007 & -2.792 & -3.229 \\
\hline$P$-value & $<0.001^{\star *}$ & $0.016^{* *}$ & $0.046^{* *}$ & $0.006^{* *}$ & 0.001 ** \\
\hline \multicolumn{6}{|c|}{ Analgesics } \\
\hline Yes & $51.2 \pm 10.4$ & $62.2 \pm 13.5$ & $61.7 \pm 20.3$ & $56.9 \pm 9.54$ & $57.9 \pm 9.39$ \\
\hline No & $65.4 \pm 15.9$ & $67.4 \pm 15.5$ & $66.1 \pm 19.4$ & $63.1 \pm 17.3$ & $65.5 \pm 14.8$ \\
\hline T-test & -3.041 & -1.131 & -0.761 & -1.229 & -1.736 \\
\hline P-value & $0.003^{\star \star}$ & 0.259 & 0.447 & 0.220 & 0.084 \\
\hline \multicolumn{6}{|c|}{ Surgical procedures } \\
\hline Yes & $61.0 \pm 15.7$ & $65.6 \pm 14.7$ & $64.8 \pm 18.8$ & $60.5 \pm 17.1$ & $62.9 \pm 13.9$ \\
\hline No & $69.5 \pm 15.2$ & $69.2 \pm 16.2$ & $67.3 \pm 20.4$ & $65.8 \pm 16.6$ & $67.9 \pm 15.1$ \\
\hline T-test & -3.840 & -1.655 & -0.917 & -2.211 & -2.427 \\
\hline P-value & $<0.001^{\star \star}$ & 0.099 & 0.360 & $0.028^{* \star}$ & $0.016^{\star \star}$ \\
\hline Splenect & & & & & \\
\hline
\end{tabular}




\section{Cureus}

\begin{tabular}{|c|c|c|c|c|c|}
\hline Yes & $63.1 \pm 15.4$ & $69.1 \pm 14.4$ & $67.8 \pm 19.9$ & $64.5 \pm 17.9$ & $66.1 \pm 14.9$ \\
\hline No & $64.8 \pm 16.1$ & $66.8 \pm 15.6$ & $65.5 \pm 19.4$ & $62.4 \pm 16.9$ & $64.9 \pm 14.6$ \\
\hline T-test & -0.521 & 0.769 & 0.597 & 0.614 & 0.438 \\
\hline P-value & 0.603 & 0.443 & 0.551 & 0.540 & 0.662 \\
\hline \multicolumn{6}{|c|}{ Cholecystectomy } \\
\hline Yes & $59.7 \pm 15.4$ & $64.3 \pm 13.8$ & $63.6 \pm 18.0$ & $59.4 \pm 15.9$ & $61.8 \pm 12.6$ \\
\hline No & $66.9 \pm 15.8$ & $68.5 \pm 16.0$ & $66.9 \pm 20.1$ & $64.4 \pm 17.4$ & $66.7 \pm 15.3$ \\
\hline T-test & -3.062 & -1.809 & -1.149 & -1.966 & -2.273 \\
\hline P-value & 0.002 ** & 0.072 & 0.252 & 0.051 & $0.024^{* *}$ \\
\hline \multicolumn{6}{|c|}{ Hip Arthroplasty } \\
\hline Yes & $54.3 \pm 11.2$ & $59.7 \pm 17.4$ & $55.6 \pm 18.9$ & $57.5 \pm 18.2$ & $56.8 \pm 15.4$ \\
\hline No & $65.2 \pm 16.1$ & $67.6 \pm 15.2$ & $66.5 \pm 19.3$ & $63.1 \pm 16.9$ & $65.6 \pm 14.4$ \\
\hline T-test & -2.315 & -1.717 & -1.897 & -1.097 & -2.043 \\
\hline P-value & 0.022 ** & 0.088 & 0.059 & 0.274 & $0.042^{* *}$ \\
\hline \multicolumn{6}{|c|}{ Shoulder arthroplasty } \\
\hline Yes & $35.7 \pm 2.02$ & $51.7 \pm 2.36$ & $56.7 \pm 23.6$ & $38.7 \pm 5.30$ & $45.7 \pm 3.47$ \\
\hline No & $64.8 \pm 15.8$ & $67.3 \pm 15.4$ & $65.9 \pm 19.4$ & $62.9 \pm 16.9$ & $65.2 \pm 14.5$ \\
\hline T-test & -2.597 & -1.425 & -0.668 & -2.016 & -1.896 \\
\hline P-value & $0.010^{* *}$ & 0.156 & 0.505 & $0.045^{* \star}$ & 0.059 \\
\hline
\end{tabular}

TABLE 3: Statistical differences between the QoL and its domain among the medications and surgical procedure done for the patients $(n=204)$

Domain 1: Physical health; Domain 2: Psychological health; Domain 3: Social Relationship; Domain 4: Environmental; QoL: Quality of life.

P-value has been calculated using independent t-test. ** Significant at $p<0.05$ level.

\section{Discussion}

SCD is the most common monogenic disorder and a global health problem [18]. It occurs when sickle hemoglobin $(\mathrm{HbS})$ replaces normal structural hemoglobin (HbA) [19]. Notably, the clinical sequels of SCD may negatively impact a patient's QoL [20].

This study found that the younger patients had better QoL scores, which is supported by previous studies $[20,21]$. However, other studies have reported no statistical differences regarding psychological health and age in SCD patients [21]. This study determined that the female patients had higher social relationship scores, which contrasts with a previous study that could not identify any statistical differences between male and female patients [22]. Moreover, our findings support a previous study that reported lower QoL scores for patients who used narcotics [20]. This study associated hydroxyurea use with lower physical health scores, which contradicts a previous study [23] that found improvements in social life, pain recall, and general health. Similar to Ojelabi et al., we associated higher hospital admission with lower QoL scores in SCD patients [24]. One previous study revealed that comorbidities among SCD patients may significantly impact their QoL [20], and our study supports this conclusion.

SCD patients with recurrent acute splenic sequestration crises, hypersplenism, or splenic abscesses often undergo a splenectomy [9]. These indications can cause pain, which may lower QoL. If these patients undergo a splenectomy, this could lower the frequency of their hospitalization for blood transfusions, provide relief from an enlarged spleen and its symptoms, and prevent recurrent acute splenic sequestration crises and their complications [25]. However, we could not find an association between QoL and splenectomy. This might be because we did not measure QoL immediately after the operation. Also, recall bias may have influenced the results. 
Our study contradicts Shurafa et al., who found that splenectomy enhanced the QoL of hematological disease patients in the domains of vitality, general health, and mental health [11]. However, they combined SCD and thalassemia, which may have caused their QoL findings to overlap. Our study showed that the patients who underwent a cholecystectomy had lower domain scores in physical health and overall QoL. In contrast, a previous study on the general population reported no significant differences in the patients' QoL scores or their psychological symptoms [26]. This difference might be caused by the coexistence of SCD in our studied population, while the former study focused on the general population. Our study is the first to correlate cholecystectomy with QoL in SCD patients.

Another serious complication that can affect $20-50 \%$ of SCD patients is osteonecrosis of the femoral head, which can result in pain and restricted movement. Our findings significantly associated total hip arthroplasty with low QoL scores in SCD patients. However, one Saudi study suggested the opposite result [12]. Osteonecrosis can also affect the humeral head, which may necessitate shoulder arthroplasty. Our findings highlighted a significant relationship between low QoL scores and shoulder arthroplasty, while another study associated shoulder arthroplasty with high QoL scores [27].

\section{Limitations}

Aside from the limitations of the convenience sampling method, we acknowledge that it would be better to measure QoL preoperatively and postoperatively to minimize recall bias. Moreover, we did not combine the questionnaire with structured interviews, which could have enhanced data quality. Therefore, we recommend measuring QoL with structured interviews or group discussions to enhance the quality of the findings.

\section{Conclusions}

This study revealed that cholecystectomy is the most common surgical procedure among SCD patients in Saudi Arabia. The findings associated surgical procedures with lower QoL scores and cholecystectomy with lower physical health and overall QoL scores in SCD patients. In addition, the findings significantly associated hip arthroplasty with lower physical health and overall QoL scores and shoulder arthroplasty with lower physical health and environmental QoL scores. However, the findings did not associate splenectomy with a statistical difference in QoL scores.

\section{Additional Information \\ Disclosures}

Human subjects: Consent was obtained or waived by all participants in this study. College of Medicine, King Faisal University issued approval 2020-10-8. Animal subjects: All authors have confirmed that this study did not involve animal subjects or tissue. Conflicts of interest: In compliance with the ICMJE uniform disclosure form, all authors declare the following: Payment/services info: All authors have declared that no financial support was received from any organization for the submitted work. Financial relationships: All authors have declared that they have no financial relationships at present or within the previous three years with any organizations that might have an interest in the submitted work. Other relationships: All authors have declared that there are no other relationships or activities that could appear to have influenced the submitted work.

\section{Acknowledgements}

We humbly want to thank every single person who helped us in doing this study and reaching the sickle cell disease patients, with special emphasis to Mr. Zakareya AlKadhem for his kindness in helping us to reach the patients.

\section{References}

1. Alenzi FQ, AlShaya DS: Biochemical and molecular analysis of the beta-globin gene on Saudi sickle cell anemia. Saudi J Biol Sci. 2019, 26:1377-84. 10.1016/j.sjbs.2019.03.003

2. Alhumaid A, Aleidi A, Alfakhri A, Alosaimi N, Ali Y, Alzahrani M: Clinical features and outcome of sickle cell anemia in a tertiary center: a retrospective cohort study. J Appl Hematol. 2018, 9:22-8. 10.4103/joah.joah 4817

3. Ahmadi M, Shariati A, Jahani S, Tabesh H, Keikhaei B: The effectiveness of self-management programs on self-efficacy in patients with sickle cell disease. Jundishapur J Chronic Dis Care. 2014, 3:e21702. 10.17795/jjcdc-21702

4. Jastaniah W: Epidemiology of sickle cell disease in Saudi Arabia . Ann Saudi Med. 2011, 31:289-93. 10.4103/0256-4947.81540

5. Ahmed AE, Alaskar AS, McClish DK, Ali YZ, Aldughither MH, Al-Suliman AM, Malhan HM: Saudi SCD patients' symptoms and quality of life relative to the number of ED visits. BMC Emerg Med. 2016, 16:30. 10.1186/s12873-016-0096-z

6. Alsultan A, Jastaniah W, Al Afghani S, Al Bagshi MH, Nasserullah Z, Al-Suliman AM, Alabdulaali MK: Demands and challenges for patients with sickle-cell disease requiring hematopoietic stem cell transplantation in Saudi Arabia. Pediatr Transplant. 2016, 20:831-5. 10.1111/petr.12767 
7. El Mouzan MI, Al Salloum AA, Al Herbish AS, Qurachi MM, Al Omar AA: Consanguinity and major genetic disorders in Saudi children: a community-based cross-sectional study. Ann Saudi Med. 2008, 28:169-73. 10.5144/0256-4947.2008.169

8. Ghmaird A, Alnoaiji MM, Al-Blewi S, Zaki S, El-Lewi A, Ahmad N: Splenectomy in patients with sickle cell disease in Tabuk. Open Access Maced J Med Sci. 2016, 4:107-11. 10.3889/oamjms.2016.034

9. Bonnet S, Guédon A, Ribeil JA, Suarez F, Tamburini J, Gaujoux S: Indications and outcome of splenectomy in hematologic disease. J Visc Surg. 2017, 154:421-9. 10.1016/j.jviscsurg.2017.06.011

10. Buzelé R, Barbier L, Sauvanet A, Fantin B: Medical complications following splenectomy. J Visc Surg. 2016, 153:277-86. 10.1016/j.jviscsurg.2016.04.013

11. Velanovich V, Shurafa MS: Clinical and quality of life outcomes of laparoscopic and open splenectomy for haematological diseases. Eur J Surg. 2001, 167:23-8. 10.1080/110241501750069774

12. Azam MQ, Sadat-Ali M: Quality of life in sickle cell patients after cementless total hip arthroplasty . J Arthroplasty. 2016, 31:2536-41. 10.1016/j.arth.2016.04.025

13. Beverung LM, Strouse JJ, Hulbert ML, et al.: Health-related quality of life in children with sickle cell anemia: impact of blood transfusion therapy. Am J Hematol. 2015, 90:139-43. 10.1002/ajh.23877

14. Alhamdan NA, Almazrou YY, Alswaidi FM, Choudhry AJ: Premarital screening for thalassemia and sickle cell disease in Saudi Arabia. Genet Med. 2007, 9:372-7. 10.1097/gim.0b013e318065a9e8

15. Qualtrics XM: Sample size calculator \& complete guide . (2020). Accessed: September 11, 2020: https://www.qualtrics.com/blog/calculating-sample-size/.

16. Ohaeri JU, Awadalla AW: The reliability and validity of the short version of the WHO Quality of Life Instrument in an Arab general population. Ann Saudi Med. 2009, 29:98-104. 10.4103/0256-4947.51790

17. WHOQOL-BREF: introduction, administration, scoring and generic version of the assessment: field trial version, December 1996. Who.int. (2021). Retrieved 12. Accessed: January 2021, from: https://www.who.int/publications/i/item/WHOQOL-BREF.

18. Piel FB, Steinberg MH, Rees DC: Sickle cell disease. N Engl J Med. 2017, 376:1561-73. 10.1056/NEJMra1510865

19. Piel FB, Hay SI, Gupta S, Weatherall DJ, Williams TN: Global burden of sickle cell anaemia in children under five, 2010-2050: modelling based on demographics, excess mortality, and interventions. PLoS Med. 2013, 10:e1001484. 10.1371/journal.pmed.1001484

20. Fisak B, Belkin MH, von Lehe AC, Bansal MM: The relation between health-related quality of life, treatment adherence and disease severity in a paediatric sickle cell disease sample. Child Care Health Dev. 2012, 38:204-10. 10.1111/j.1365-2214.2011.01223.x

21. McClish DK, Smith WR, Levenson JL, Aisiku IP, Roberts JD, Roseff SD, Bovbjerg VE: Comorbidity, pain, utilization, and psychosocial outcomes in older versus younger sickle cell adults: the PiSCES project. Biomed Res Int. 2017, 2017:4070547. 10.1155/2017/4070547

22. van Tuijn CF, van Beers EJ, Schnog JJ, Biemond BJ: Pain rate and social circumstances rather than cumulative organ damage determine the quality of life in adults with sickle cell disease. Am J Hematol. 2010, 85:532-5. 10.1002/ajh.21731

23. Ballas SK, Barton FB, Waclawiw MA, et al.: Hydroxyurea and sickle cell anemia: effect on quality of life . Health Qual Life Outcomes. 2006, 4:59. 10.1186/1477-7525-4-59

24. Ojelabi AO, Bamgboye AE, Ling J: Preference-based measure of health-related quality of life and its determinants in sickle cell disease in Nigeria. PLoS One. 2019, 14:e0223043. 10.1371/journal.pone.0223043

25. Mishra B, Nayak M, Mishra S, Das I: Splenectomy in sickle cell haemoglobinopathies. Int Surg J. 2019, 6:

26. Talseth A, Edna TH, Hveem K, Lydersen S, Ness-Jensen E: Quality of life and psychological and gastrointestinal symptoms after cholecystectomy: a population-based cohort study. BMJ Open Gastroenterol. 2017, 4:e000128. 10.1136/bmjgast-2016-000128

27. Cho CH, Song KS, Hwang I, Coats-Thomas MS, Warner JJ: Changes in psychological status and healthrelated quality of life following total shoulder arthroplasty. J Bone Joint Surg Am. 2017, 99:1030-5. 10.2106/JBJS.16.00954 